\title{
CORRECTION
}

\section{Correction to: A New Perspective on the Brittle-Ductile Transition of Rocks}

\section{G. Walton ${ }^{1}$}

Published online: 16 October 2021

(c) Springer-Verlag GmbH Austria, part of Springer Nature 2021

\section{Correction to: Rock Mechanics and Rock Engineering https://doi.org/10.1007/s00603-021-02595-9}

After publication, the author became aware that a derivation similar to the one presented in Sect. 3.1 of this paper had previously been published. Specifically, it should be noted that when $d=3.4$ (i.e. "Mogi's Line") is substituted into Eq. (11), it simplifies to be equivalent to the equation for $\sigma_{3}^{*}$ derived in Appendix A.2 of the doctoral thesis of Rahjoo (2019).

\section{Reference}

Rahjoo M (2019) Directional and 3-D confinement-dependent fracturing, strength and dilation mobilization in brittle rocks. Ph.D. Thesis. University of British Columbia

Publisher's Note Springer Nature remains neutral with regard to jurisdictional claims in published maps and institutional affiliations.

The original article can be found online at https://doi.org/10.1007/ s00603-021-02595-9.

\footnotetext{
G. Walton

gwalton@mines.edu

1 Colorado School of Mines, Golden, CO, USA
} 